ARTIGO TEMATTCO: ESTADO, ECONOMIA E DEMOCRACIANO BRASIL E AMÉRICA LATINA

\title{
Crise econômica, luta de classes e Serviço Social no Brasil
}

\author{
Adilson Aquino Silveira Júnior \\ Universidade Federal de Pernambuco, Departamento de Serviço Social, \\ Recife, PE, Brasil (UFPE)
}

\section{Crise econômica, luta de classes e Serviço Social no Brasil}

Resumo: O texto objetiva analisar a crise econômica presente na realidade brasileira a partir de 2011, assinalando seus impactos sociais e políticos, em especial suas consequências para um acirramento da luta de classes no país. Aborda também a agenda restauradora que as classes dominantes estão impondo para resolução da crise. Em face desse quadro econômico e político, o texto visa, ainda, refletir sobre as tendências ideológicas e políticas conciliatórias tradicionalmente presentes no Serviço Social, e como o Conselho Federal de Serviço Social aponta uma alternativa estratégica para a inserção da profissão na realidade brasileira através do tema proposto para o Dia do/a Assistente Social de 2017: Na luta de classes não há empate - Assistente Social: profissional em defesa das liberdades democráticas e dos direitos sociais. Para tanto, foi realizado um estudo utilizando fontes bibliográficas e documentais.

Palavras-chave: Crise econômica. Lutas de classes. Ideologia. Serviço Social.

\section{Economic Crisis, Class Struggle and Social Work in Brazil}

Abstract: The purpose of this text is to analyze the economic crisis in Brazil since 2011, indicating its social and political impacts, particularly its consequences for an intensification of the class struggle in the country. It also addresses the restorative agenda that the dominant classes are imposing for the resolution of the crisis. In light of this economic and political situation, the article also reflects on the conciliatory ideological and political tendencies traditionally found in social work, and how the Federal Social Work Council offers a strategic alternative for the insertion of the profession in the Brazilian reality through the theme proposed for the day of the social worker of 2017: In the class struggle there is no tie-Social Workers: professionals in defense of democratic liberties and social rights. To do so, a study was conducted of bibliographic and documentary sources.

Keywords: Economic crisis. Class struggle. Ideology. Social Work.

Recebido em 30.05.2017. Aprovado em 05.09.2017. Revisado em 27.11.2017.

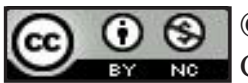

(C) O(s) Autor(es). 2018 Acesso Aberto Esta obra está licenciada sob os termos da Licença Creative Commons Atribuição-NãoComercial 4.0 Internacional (https://creativecommons.org/licenses/bync/4.0/deed.pt_BR), que permite copiar, distribuir e reproduzir em qualquer meio, bem como adaptar, transformar e criar a partir deste material, desde que para fins não comerciais, e que você forneça o devido crédito aos autores e a fonte, insira um link para a Licença Creative Commons e indique se mudanças foram feitas. 


\section{Introdução}

Nesse texto, buscamos analisar a crise econômica do Brasil dos últimos anos, sinalizando para seus impactos sociais e políticos, e para a agenda restauradora das classes dominantes e frações dirigentes no governo $^{1}$. Avaliamos como a crise coopera para deflagrar um acirramento da luta de classes no país, sinalizando para as suas possibilidades de desdobramento. Tendo em vista o quadro econômico e político forjado pela crise brasileira, apresentamos, ainda, uma reflexão sobre o tema proposto pelo Conselho Federal de Serviço Social (CFESS) para as atividades de celebração do Dia do/a Assistente Social de 2017: Na luta de classes não há empate - Assistente Social: profissional em defesa das liberdades democráticas e dos direitos sociais. Para além de contestar tendências ideológicas e políticas arraigadas na história do Serviço Social (tendências cujos principais traços resgatamos nesse artigo), enfatizamos que esse tema possui um alcance muito mais amplo, transbordando o debate profissional, ao fortalecer mesmo uma perspectiva estratégica para o enfrentamento da crise.

\section{A crise econômica e seus impactos}

Não raras vezes, a obra de Marx sinalizou para a possibilidade de aferirmos o enraizamento de um fenômeno social (ou de determinadas legalidades sociais) pela intensidade com que esse fenômeno se entranha no senso comum, se cristaliza na cultura das massas populares ${ }^{2}$. Utilizando esse critério de interpretação histórica, argutamente captado e desenvolvido por Gramsci (2011a), poderíamos dizer que o quadro de crise econômica que experimentamos hoje é profundo. Parece muitíssimo generalizada na mentalidade das classes trabalhadoras e subalternas no país a constatação de que vivemos uma crise (algo um tanto recente, considerando a última década). Mas, mais que isso: se torna lugar-comum a convicção de que se faz necessário reorganizar o modo de vida de acordo com as condições restritivas, de carecimento social, de incremento do custo de vida, e mesmo de acirramento da violência e da insegurança, que a estabelecimento da crise supõe - lugar-comum para o qual cooperam as investidas da aparelhagem hegemônica à disposição das classes dominantes, reatualizando a chamada "cultura da crise", como afirma Mota (2017, p. 40). Em suma, tem se universalizado, com certa intensidade, o entendimento de que é imperativo adaptar-se à atmosfera de incerteza e penúria social própria da crise. $\mathrm{O}$ que ganha aderência devido a um fato concreto: com efeito, atravessamos esse estágio que reincide ciclicamente na realidade capitalista, diga-se, a crise econômica e seus corolários sociais e políticos.

Essa conjuntura econômica se deflagrou por volta de 2011, após um período de relativa expansão, que vinha se estendendo desde $2004^{3}$. Não iremos detalhar as características do modelo de crescimento que sustentou essa fase de expansão ${ }^{4}$. Apenas sinalizamos que as contradições inerentes a esse avanço do capitalismo brasileiro na segunda metade dos anos 2000 perpetuaram as circunstâncias que vulnerabilizam a economia, germinando as vicissitudes econômicas, sociais e políticas da fase seguinte. A crise é resultado das contradições que se acumulam durante a própria expansão. De modo amplo, o projeto de desenvolvimento para o qual cooperaram o governo petista e seu arco de alianças aprofundou o caráter dependente do país, se esquivou de enfrentar suas contradições sociais estruturais e constituiu-se refém das oscilações econômicas por que passam os países centrais. Quando as nações imperialistas começam a vivenciar um momento de contração após 2010, levam a reboque o ciclo expansivo brasileiro, que maciçamente dependia da demanda externa. ${ }^{5}$ Com isso, o ímpeto ascendente da taxa de crescimento do PIB brasileiro - que já havia sido abalado em 2008 - é substituído por uma trajetória declinante, em 2011, no início do primeiro governo Dilma. E essa trajetória declinante da economia brasileira permanece assim até o momento atual (junho de 2017). A partir de finais de 2014, essa desaceleração se torna uma depressão econômica, com taxas de crescimento negativas cada vez mais acentuadas - apenas entre finais de 2016 e início de 2017, observa-se uma atenuação adjetiva dessas taxas negativas, porém sem nenhuma certeza de saída desse quadro.

As manifestações desse cenário se expressam em diferentes nuances da conjuntura econômica. Além da baixa nas taxas de crescimento do Produto Interno Bruto (PIB), vemos, após 2013: queda na produção industrial, com redução do faturamento industrial, acréscimo na ociosidade da capacidade de produção, redução na quantidade de horas trabalhadas na produção (CONFEDERAÇÃO NACIONAL DAS INDÚSTRIAS, 2015); déficit da balança comercial, aumento da inflação e crescimento da dívida pública (que passa de $56 \%$ do PIB no final de 2014, para 70\% do PIB no final de 2016); eclosão de déficits nas contas públicas - o que ocorre a partir de 2014, quando se registra o primeiro déficit desde o início da série histórica, em 1997; e um assombroso aumento do desemprego - a Pesquisa Nacional por Amostra de Domicílios (PNAD/IBGE) Contínua aponta que a taxa de desemprego dobra entre 2014 e 2017 , passando de $6,5 \%$ para $13,7 \%$, multiplicando-se por dois o 
número de desempregados no país (eram 7 milhões em 2014, e, em 2017, são 14,2 milhões). Nesse universo, a informalidade cresce, com a perda de 3 milhões de postos com carteira assinada, entre 2014 e maio de 2017. Não é por acaso que estamos observando um estágio de inquietação social acentuado e bastante complexo, no qual o grau dos atritos entre as classes e suas frações distingue-se daquele observado nos anos anteriores. Uma fase que nos parece expressar um momento novo da luta de classes no país.

\section{As lutas de classes durante a crise}

As lutas sociais e os enfrentamentos entre as frações dirigentes no Estado entraram num ritmo novo no curso da crise. Desde 2008, já se tornava perceptível a existência de um estado de inquietação social dos subalternos no Brasil, ocasionado pelas próprias vicissitudes da fase expansiva. Vemos, por exemplo, que, a partir de 2008, a estatística das greves opera uma virada ascendente, depois da queda experimentada nos anos 1990 e da tendência de estabilização entre 2002 e 2007 (NORONHA, 2009; BRAGA, 2016). O ciclo expansivo apresenta contradições que pesam sobre a classe trabalhadora. Diz Braga (2016) que, após 2008, essas contradições acirram as tensões em entre a regulação política (chamada de hegemonia lulista ou lulismo) e a acumulação econômica (marcada pelos dramas da expansão periférica). Ou seja, enfraquece a capacidade dessa modalidade de supremacia burguesa de pacificar conflitos sociais. Com o tempo, vai se tornando árduo o trabalho de manter o controle da inquietação dos/as trabalhadores/as em face das contradições experimentadas no curso do propalado crescimento econômico - veja-se, por exemplo, o aumento do emprego e da formalidade paralelo à compressão do trabalho na base da pirâmide social (equalização por baixo dos salários), à existência de maiores jornadas e ao crescimento do número de acidentes de trabalho; ou o crescimento do consumo caminhando pari passu com o aumento do endividamento das famílias (BRAGA, 2016; LUCE, 2013; POCHMANN, 2012).

A crise veio para alastrar de vez essas tensões, e anunciar uma possível saturação da capacidade da hegemonia lulista de represar a inquietação social acumulada. E, ademais, a crise alerta para os limites tangíveis que essa hegemonia conteria, no sentido de evitar as resistências à agenda ainda mais nefasta necessária para resolver a crise. Se essa modalidade de hegemonia perde a capacidade de regulação política nas circunstâncias da crise, ela tende a se tornar supérflua, tende a ser desinteressante como instrumento de domínio das classes possuidoras no país. Daí o desgaste do governo e a força dos movimentos pró-impeachment após as eleições de 2014.

Um quadro ilustrativo, embora esquemático e aproximativo, da evolução dessas tensões sociais no Brasil pós-2008, pode ser esboçado do seguinte modo. Já mencionamos que nos quatro anos que se seguem (20082012), aumentam as greves: o número de paralisações dobra, e, emparelhadas com as lutas de caráter defensivo, alastram-se as mobilizações de cunho propositivo. No curso mesmo em que se deflagrava a contração econômica, após 2012, a movimentação social no Brasil se intensifica. Para Braga (2016), o ano de 2013 consiste no ponto de convergência entre essa luta econômica da classe trabalhadora organizada sindicalmente (expressa na ação grevista) e a luta política dos assalariados urbanos nas ruas pela defesa dos seus direitos sociais. Nesse ano, para além das greves que vinham num crescente, vemos a explosão de protestos que marcaram o mês de junho; logo em seguida, se insurgem as mobilizações populares contra os megaeventos, especialmente as ocorridas durante a Copa do Mundo da Federação Internacional de Futebol (FIFA) de 2014; no início de 2015, se organizam massivas manifestações pró-impeachment (e essas manifestações expressam como a crise aprofundou o ressentimento das classes médias tradicionais e urbanas com o governo petista); já no começo de 2016, são preparados atos em defesa da democracia e contra o impeachment de Dilma Rousseff, que ocorrem em disputa com aquelas mobilizações dos apoiadores da saída da presidenta. No contexto do governo Temer, nos deparamos com a chamada Primavera Secundarista (de outubro a dezembro de 2016) um movimento de ocupação das escolas contra a Proposta de Emenda Constitucional (PEC) 241/Emenda Constitucional (EC) 95 de 2016 (BRASIL, 2016a) do congelamento dos gastos públicos, o Projeto de Lei (PL) n ${ }^{\circ}$ 193/2016 (BRASIL, [2016b]), conhecido como Escola sem Partido, a Medida Provisória (MP) n 746/ 2016 (BRASIL, [2017a]) da reforma do Ensino Médio, dentre outras iniciativas de nível regional. Aqui cabe destacar a expressividade dessas ocupações: foram perto de 1200 ocupações, em 22 estados brasileiros, organizadas em escolas, institutos federais e universidades. Ao mesmo tempo (out. e dez. 2016), se desenrolam os protestos específicos contra a PEC 241/EC 95 de 2016 (BRASIL, 2016a) em várias partes do país; e, no primeiro semestre de 2017, vemos as paralisações e mobilizações pela Greve Geral, contra a reforma da previdência e trabalhista, além daquelas pela saída do Presidente.

Toda essa movimentação social deflagrada após 2008, e atiçada com a irrupção da crise econômica, pode significar a entrada em um novo estágio da luta de classes no Brasil, do qual os eventos acima citados são 
apenas os exemplos mais conhecidos. O que não garante a priori uma resolução da crise em benefício de qualquer das classes e frações envolvidas. Mas adverte para o fato de que a capacidade de fazer estancar a ofensiva da agenda restauradora das classes dominantes depende da decisão consciente das massas trabalhadoras de defender uma política de independência de classe - aquilo que Gramsci (2011b, p. 79) chama "espírito de cisão" -, abandonando as tendências conciliatórias tão fortes no passado recente.

Numa palavra: para frear qualquer retrocesso, é preciso uma estratégia $d a$ classe trabalhadora, voltada para uma reorganização da sociedade segundo suas necessidades históricas. Tal horizonte se expressa em três dimensões distintas, mas intrinsecamente articuladas: $1^{\text {a }}$ ) na necessária recorrência aos instrumentos de luta e pressão criados pelo movimento operário que implicam diretamente na esfera econômica das relações entre as classes - isso significa o privilégio em torno da ação grevista e das ocupações, caucionadas em mobilizações de massa, com a consequente recusa da negociação das perdas (de empregos, salários e direitos) em esferas institucionais e burocratizadas; $2^{\mathrm{a}}$ ) na edificação de alternativas construtivas para a crise que subvertam a apropriação privada dos meios de produção e do excedente econômico, a expropriação da riqueza e do poder político das massas trabalhadoras; e, $3^{\text {a }}$ ) na afirmação de uma política abrangente de solidariedade de classe - balizada pela direção geral dada nas dimensões anteriores - que rescinda o corporativismo e a segmentação das diversas lutas pelas quais se expressam a revolta contra a exploração, alienação e opressão no contexto da crise. Enquanto essa saída permanece periférica no bojo das lutas, e carente de eficácia histórica, são as classes possuidoras e dominantes no país que estão avançando numa política e numa reorganização da sociedade brasileira segundo seus interesses de supremacia. Vejamos um resumo do gigantesco ataque deslanchado desde 2014, quando a desaceleração econômica começava a se expressar através de taxas de crescimento negativas.

\section{Agenda restauradora para o desfecho da crise}

A história das lutas de classe parece indicar sempre que quando o ritmo produtivo das indústrias cai, que quando se instala a abstinência da produção fabril, levada a efeito pela crise, é o Estado capitalista que passa a operar a todo vapor, colocando velozmente sua maquinaria em pleno funcionamento para socializar os custos do colapso econômico, para acirrar as taxas de exploração, para onerar os de baixo nas tentativas de recuperação do sistema. A situação do Brasil nesse quadro conjuntural não é diferente. De fato, as saídas propostas para o desenlace da crise, pensadas e implantadas a partir de 2014, se apresentam como um caso exemplar disso. As frações dirigentes no governo passam a trabalhar num ritmo febril para reanimar as taxas de lucro e crescimento.

Nos momentos finais do primeiro governo Dilma, cabe recordar como, no apagar das luzes de 2014, tivemos a aprovação das MPs n 664 (BRASIL, [2015a]) e nº 665 (BRASIL, [2015b]) (30 dez. 2014), convertidas em lei em 2015 (leis no 13.134, de 14 jun. 2015 (BRASIL, 2015c), e n 13.135, de 17 jun. 2015 (BRASIL, 2015d)), cujo objetivo foi aumentar a rigidez para acesso de alguns benefícios previdenciários. Também a partir de 2014, seguem-se um conjunto de decretos que buscam o contingenciamento orçamentário para garantir o superávit primário (até jul. de 2015, o corte foi de $\mathrm{R} \$ 80$ bilhões nas despesas sociais, através do Decreto 8.496, de 30 jul. 2015 (BRASIL, 2015e), e do Decreto 8.456, de 22 mai. 2015 (BRASIL, 2015f)). Naquele momento, vemos ainda o aumento da previsão do gasto com o serviço da dívida pública, que alcançou $R \$ 1,3$ trilhões, para 2015. Além do aumento da taxa de juros, a Taxa SELIC (Sistema Especial de Liquidação e de Custódia) (que subiu de $11,65 \%$ para $14,25 \%$ em set. 2015), demonstrando a disposição do governo em aumentar a remuneração do capital financeiro em meio à contenção de recursos. Seguido da publicação da MP nº 680 (de 6 jul. 2015 (BRASIL, [2015g]), convertida na Lei no 13.189, de 19 nov. 2015 (BRASIL, 2015h)) que instituiu o Programa de Proteção ao Emprego, permitindo às empresas com dificuldades econômico-financeiras a redução temporária da jornada de trabalho dos empregados, com a redução proporcional do salário (compensada parcialmente pelo próprio governo através dos recursos do Fundo de Amparo ao Trabalhador - FAT) ${ }^{6}$

O governo Temer, por sua vez, tem demonstrado que seus escrúpulos para implantar medidas que penalizam a vida dos/as trabalhadores/as são próximos de zero. Sua plataforma regressiva para estancar a estagnação já havia sido esboçada no documento Ponte para o futuro (PARTIDO DO MOVIMENTO DEMOCRÁTICO BRASILEIRO, 2015), antes de empalmar o executivo federal. Uma síntese da agenda restauradora pode ser apresentada em seis eixos, segundo Queiroz (2017, p. 4):

1) a desindexação geral [ou seja, quebra do reajuste automático de preços e salários de acordo com a inflação];

2) a desvinculação orçamentária, especialmente das despesas com educação e saúde, e redução do gasto público; 
3) a privatização, a descentralização e as parcerias público-privadas amplas;

4) a abertura da economia, inclusive com o fim do conteúdo local ou nacional; ${ }^{7}$

5) a reforma trabalhista, com livre negociação, incluindo a prevalência do negociado sobre o legislado nas relações de trabalho, a terceirização e a pejotização, [que, na prática, aponta para o fím da Consolidação das Leis do Trabalho (CLT) como baliza para regular as proteções do trabalho];

6) a nova reforma da Previdência, com aumento da idade mínima, unificação de regimes previdenciários e desvinculação do salário mínimo como piso de benefício previdenciário, entre outros.

As medidas que pairam como uma sombra ameaçando futuro imediato das massas trabalhadoras, ou já se afirmam como uma realidade, ou estão chegando bem próximo disso, por volta de maio de 2017: a Emenda Constitucional que congela o gasto público (EC n 95/2016 (BRASIL, 2016a)), a PEC 287/2016 (BRASIL, [2016c]) da Reforma da Previdência, os projetos de terceirização e prevalência do negociado sobre o legislado, dentre outros. E, para isso, o governo atual conta com ampla maioria nas instâncias decisórias do Estado. Queiroz (2017) classifica do seguinte modo a oposição e a base de apoio nesse momento: são 413 deputados na Câmara que formam a base do governo, contra apenas 100 na condição de oposição; no Senado, o governo conta 65 senadores contra somente 16 da oposição. Apenas esses números já denunciam a situação de forças desfavorável, e os riscos de depositar as expectativas de mudança exclusivamente nessas instâncias decisórias ${ }^{8}$.

A subordinação do poder político pelas forças da acumulação no regime capitalista exige que qualquer debate sobre o aprofundamento da democracia (e, inclusive, dos direitos sociais) deve necessariamente contemplar os problemas relativos socialização da posse e apropriação da propriedade e da riqueza (WOOD, 2003). Sobre isso, basta uma constatação sinalizada por Bava (2017), acerca das eleições de 2014, de onde saiu essa composição de forças extremamente assimétrica: no pleito eleitoral daquele ano, investindo cerca de R\$ 5 bilhões, dez grupos econômicos elegeram 70\% do Congresso Nacional. O mesmo Congresso que hoje conta com essa maioria empenhada em garantir as políticas de austeridade.

Estudos da Associação Nacional dos Auditores Fiscais da Receita Federal do Brasil (ANFIP) e do Departamento Intersindical de Estatística e Estudos Socioeconômicos (DIEESE) (ANFIP; DIEESE, 2017; ANFIP 2016; DIEESE, 2016) já apontam os impactos sociais destrutivos da EC n 95/2016 (BRASIL, 2016a): retirada do poder de controle do Poder Executivo, do Congresso e da sociedade sobre o tamanho do orçamento, agora automaticamente engessado por vinte anos; para servidores públicos, a desvalorização, com possibilidades de corte de direitos e reajustes, contenção de novas contratações (estancando abertura de novos concursos). Além disso, as projeções apontam forte redução da receita corrente líquida, até 2036, para a Educação (de 18\% para 11,3\%) e Saúde (de 15\% para 9,3\%); e, com isso, fortes pressões para desvinculações, reforma na Previdência, etc.

No caso da Reforma da Previdência, as mudanças implicarão no alongamento do tempo de contribuição e na redução do valor das aposentadorias, falta de atratividade da previdência pública e reforço da atuação do setor privado. O principal conteúdo altera: 1) a forma de acesso a benefícios; 2) a forma de cálculo do benefício; 3) o financiamento de todos os regimes previdenciários. Em prejuízo dos/as segurados/as, as mudanças atingem, portanto, os três principais fundamentos considerados para efeitos da concessão de benefício: 1) a idade, que é aumentada; 2) o tempo de contribuição, que é ampliado; 3) o valor do benefício, que é reduzido. Ocorre que nessa cruzada dos porta-vozes da burguesia contra os gastos sociais, não se faz referência, por exemplo, aos custos com juros sobre a dívida pública (superior aos gastos previdenciários em 2015); à perda de receitas por conta das renúncias tributárias concedidas pelo governo (quase o triplo do suposto déficit da Previdência em 2015); nem ao fato de que anualmente a União deixa de arrecadar mais de um orçamento da Previdência, porque não há políticas eficazes de combate à sonegação físcal (ANFIP; DIEESE, 2017). Ou seja, trata-se de uma indignação seletiva, onde se afirma um claro filtro de classe sobre os projetos de enfrentamento da crise.

Em suma, hoje todos os poderes do Estado brasileiro estão empenhados, trabalhando de modo orquestrado, para usurpar os/as trabalhadores/as. Na síntese oferecida por Queiroz (2017), temos:

- O Executivo, tratando especialmente do aspecto fiscal, através das medidas de corte de despesas e aumento das receitas extraordinárias, agindo para: aprovação da EC n 93/2016 (BRASIL, 2016d), para a prorrogação da Desvinculação de Receitas da União (DRU), a desvinculação das receitas dos estados e municípios (até 2023); aprovação da EC nº 95/2016 (BRASIL, 2016a), para congelamento dos gastos por vinte anos (já sancionada); apresentação da PEC n 287/2016 (BRASIL, [2016c]), da reforma da previdência; aprovação e sanção da Lei n 13.291/2016 (BRASIL, 2016e), que altera a meta fiscal de 2016; regulamentação da Lei n 13.254 (BRASIL, 2016f), que trata da repatriação de recursos (facilitando a regularização de capitais no exterior); apresentação da Lei $n^{\circ}$ 13.415/2017 (BRASIL, 2017b), que trata do novo ensino médio (acarretando a diluição de disciplinas 
estruturantes do currículo; a falsa premissa da escolha da formação no sistema público; e o atestado de notório saber); dentre outras.

- O Legislativo trabalha para melhoria do ambiente de negócios, suprimindo ou flexibilizando direitos, e abrindo a economia ao capital privado nacional e estrangeiro, buscando sancionar: a Lei ${ }^{\circ} 13.303 /$ 2016 (BRASIL, 2016g), sobre o estatuto jurídico da empresa pública, economia mista e subsidiárias, nos três níveis de governo; a Lei n ${ }^{\circ} 13.334 / 2016$ (BRASIL, 2016h), que cria o Programa de Parcerias de Investimento (PPI); a Lei n ${ }^{\circ}$ 13.299/2016 (BRASIL, 2016i), que facilita os leilões e concessões públicos; a Lei $n^{\circ}$ 13.360/2016 (BRASIL, 2016j), que altera os marcos regulatórios da energia elétrica no Brasil; a Lei no 13.365/2016 (BRASIL, 2016k), que dispõe sobre o fim da Petrobras como operadora única do pré-sal. Além de buscar avançar na aprovação, pelo Senado, do Projeto de Lei Complementar (PLP) 268/2016 ([2017c]), que aumenta a presença de profissionais de mercado nas esferas de decisão dos fundos de pensão; a votação da terceirização na atividade fim das empresas (Projeto de Lei da Câmara (PLC) 30/2015 (BRASIL, [2017d]) no Senado e PL 4.320/1998 na Câmara (BRASIL, [2000])) e o PL 6.787/2016 (BRASIL, [2017e]), que trata da prevalência do negociado sobre o legislado.

- O Judiciário, com seu ativismo judicial, julgando no Supremo Tribunal Federal várias matérias em sintonia com a missão perseguida nos outros poderes, tais como: a fim da desaposentação (Recursos Extraordinários (RE) 381.367, 661.256 e 827.833); o desconto dos dias paralisados em caso de greve do servidor (RE 693.456); o fim da ultratividade da norma (Arguição de Descumprimento de Preceito Fundamental (ADPF) 323) - o que significa que um acordo de convenção coletiva deixa de vigorar, após expirado o prazo, se a empresa ou entidade patronal se recusa a negociar; a quitação plena dos Programas de Desligamento Voluntário (PDV) ou Programa de Demissão Incentivada (PDI) - RE 590.415; a prevalência do negociado sobre o legislado (RE 590.415 e 895.759); a possibilidade de votar, inclusive com repercussão geral, a inconstitucionalidade da Súmula 331 do Tribunal Superior do Trabalho (TST), o que permitiria a liberação da terceirização de atividade-fim (RE 958.252).

Em face dessa avalanche restauradora, queremos refletir sobre o significado da posição política que o CFESS provoca através do tema escolhido para comemorar o Dia do/a Assistente Social em 2017. Acreditamos que a abrangência e o alcance desse tema são bastante amplos, ultrapassando o marco temporal do ano em questão, na medida em que corrobora mesmo uma perspectiva estratégia para enfrentamos a crise (inobstante seus desdobramentos políticos mais ou menos regressivos, progressistas, etc.).

\section{Serviço Social na luta pela construção de estratégias pautadas na independência de classe}

No informativo anual do conjunto CFESS-CRESS de 2017, Serviço Social é Notícia $n^{\circ} 3$, encontramos a justificativa do tema do Dia do/a Assistente Social: Na luta de classes não há empate - Assistente Social: profissional em defesa das liberdades democráticas e dos direitos sociais. Assim afirma o CFESS:

[...] o trabalho de assistentes sociais não se desenvolve de forma neutra no contexto de uma sociedade de classes, que cotidianamente penaliza usuários/as com a desigualdade social, e em um país cujo ajuste estrutural do Estado resvala contra os direitos sociais conquistados pelos/as trabalhadores/as. Os princípios construídos pela profissão se materializam no cotidiano pelo reconhecimento de que temos um lado e de que, na sociedade de classes, não há empate. (CFESS, 2017, p. 5).

A constatação Na luta de classes não há empate!, levantada pelo tema de 2017, apresenta um chamamento muito claro, portanto: é imperativo assumir o lado dos/as trabalhadores/as na luta de classes e recusar qualquer perspectiva conciliatória ou de neutralidade. Na trajetória histórica do Serviço Social, isso significa uma grande reviravolta, que entra em colisão com disposições político-ideológicas arraigadas na cultura profissional desde muito tempo. Desde, ao menos, os principais estágios pelos quais passou a profissão no Brasil até o desenlace da sua renovação crítica - e mesmo no curso da chamada intenção de ruptura (NETTO, 2004), estratégias conciliatórias não deixaram de se fazer presentes entre as tendências profissionais.

Enfatizamos, com isso, que predominou um tradicional posicionamento de conciliação e neutralidade no Serviço Social durante sua história (ao menos até a intenção de ruptura). Uma defesa da conciliação e da neutralidade que, inclusive, parecia estar em contradição com a sua continuamente declarada postura anticomunista.

Cabe lembrar que o Serviço Social brasileiro, nascido nos anos 1930, emerge lastreado na vertente mais direitista do pensamento católico europeu, e, principalmente, nas encíclicas papais. Por isso, ele se mostrava essencialmente doutrinário e apologético no entendimento mais amplo da sociedade. Rechaçava o comunismo 
totalitário e a ordenação social do liberalismo, apostando numa terceira via entre liberalismo e comunismo. Acreditava que ambos seriam incapazes de responderem ao problema das classes subalternas. Problema que se supunha fundado por uma pretensa crise mais profunda, desdobrada com a secularização da sociedade brasileira - e para cuja resolução apontava-se a recristianização e reorganização dessa sociedade na ótica do corporativismo cristão. O Serviço Social no país emerge, pois, num momento de redefinição do papel da Igreja, em face da consolidação do ordenamento burguês; surge, como um departamento especializado da Ação Social e da Ação Católica (IAMAMOTO; CARVALHO, 2005).

Os eixos nucleares da visão política eram a conciliação entre capital e trabalho e a terceira via entre liberalismo e socialismo. Aqui já conseguimos notar o alcance do tema do CFESS de 2017, que nos convoca para o rompimento com posturas tão entranhadas na história do Serviço Social. Mas essa visão não se esgota nos anos 1930-1950. Mesmo quando a profissão começa a passar por um processo de atualização, articulado com o avanço da hegemonia norte-americana na América Latina; ou seja, por uma busca de atualização matizada por um perfil técnico pretensamente mais científico e modernizante, e gravitando em torno das novas exigências colocadas pelas experiências de implantação do Desenvolvimento de Comunidade; mesmo nesse novo estágio, se reitera a convocação à neutralidade do Serviço Social face aos interesses das classes que dinamizavam a sua atuação.

Caso emblemático disso consiste num dos debates que ocorrem no $1^{\circ}$ Congresso Pan-Americano de Serviço Social (no Chile, em 1945), no qual se observa uma importante participação de representantes brasileiros. Naquela ocasião existiu uma disputa de posicionamentos políticos em torno dos debates do Serviço Social na Indústria. Os estudos de Iamamoto e Carvalho (2005, p. 329) identificam que uma ala então considerada "mais avançada" defende um Serviço Social ao lado dos operários, ratificando, inclusive, que "[...] as organizações operárias são as únicas legítimas fontes mantenedoras dos Assistentes Sociais". Essa ala é derrotada, naquele momento. No embate, o que prevalece amplamente é a posição que afirma o caráter de neutralidade e conciliação entre capital e trabalho. Ou seja, o Serviço Social, na abertura de um novo estágio profissional, indicava manter uma avaliação de sua posição e intervenção na sociedade como sendo uma instituição acima das classes e seus antagonismos. Na evolução desse novo estágio, o que domina é uma visão de desenvolvimento harmônica. ${ }^{9}$ Mais especificamente, na aproximação com o pensamento desenvolvimentista ocorrida no Serviço Social brasileiro nos anos 1960, o discurso é de um "desenvolvimento harmônico e humano", de um desenvolvimento nacional que beneficiaria a todos, sem distinção (IAMAMOTO; CARVALHO, 2005, p. 347).

\section{[...] a capacidade de fazer}

estancar a ofensiva da agenda restauradora das classes

\section{dominantes depende da decisão} consciente das massas

\section{trabalhadoras de defender uma} política de independência de

$$
\text { classe [...] }
$$

Assim, nos anos 1960, e boa parte dos anos 1970, é robustecida a autoafirmação do/a assistente social com um/ a agente técnico/a, do/a qual é exigida uma visão modernizante, e cuja eficiência dependia da utilização produtiva dos métodos científicos, principalmente da ciência social aplicada (planejamento, psicologia social, antropologia aplicada). No limite, um agente de mudança social para o desenvolvimento integral do homem - donde, também, se mostra o sincretismo do discurso modernizante com a visão tradicional. A novidade dessas décadas é que a posição supraclassista (e de neutralidade) começa a aparecer também metamorfoseada na afirmação de uma objetividade dos instrumentos técnico-científicos aplicados pelo Serviço Social. Se expressa no fetiche da técnica e da ciência a defesa de uma pretensa neutralidade profissional. Reduzindo-se a chamada questão social a problemas técnicos, pretensamente neutros, acima das classes. ${ }^{10}$

Ocorre, no entanto, que essas posturas de conciliação ou de neutralidade não são automaticamente suplantadas com a emergência e a evolução do movimento de intenção de ruptura, movimento de renovação crítica que ocorre no Serviço Social brasileiro por volta da década 1970 em diante. Embora, nesses anos, a profissão tenha consolidado laços com as lutas das classes trabalhadoras e suas bandeiras históricas, e se vinculado, nos anos 1990, ao "[...] processo de construção de uma nova ordem societária, sem dominação, exploração de classe, etnia e gênero" (BRASIL, 2012, p. 24); embora esse giro tenha ocorrido, a profissão não ficou imune a estratégias de conciliação de classes, ou isenta de leituras meramente técnicas e neutras do significado social de seu papel na reprodução da sociedade. ${ }^{11}$ Sobre a persistência de posições conciliatórias, basta observamos como alcançou certa aderência no corpo profissional, em setores de sua intelectualidade, e mesmo em segmentos dirigentes 
corporativos, a aposta em um "desenvolvimento integral" (ANANIAS, 2010, p. 315) feita pelo governo petista durante sua permanência no executivo federal.

Não pretendemos deslindar, nem os conteúdos e as determinantes sociais das reviravoltas no projeto político do Partido dos Trabalhadores (PT) (das quais resultou a adoção do crescimento com inclusão social), nem o impacto social (mais ou menos significativo) da sua atuação nas condições de vida das classes trabalhadoras (ou nos negócios das classes dominantes), nem toda a relação que o Serviço Social cultivou com a construção do partido, ou as condicionantes internas da profissão que possam ter cooperado para uma aproximação à ideologia do dito neodesenvolvimentismo. Buscamos apenas ressaltar o conteúdo político desse discurso ideológico: a apologética simbiose entre crescimento econômico e desenvolvimento social; a suposta combinação harmônica entre desenvolvimento econômico e inclusão social, afirmada como possível, sob a realidade capitalista. Ou seja, uma visão de desenvolvimento que supostamente beneficiaria todas as classes sociais, indistintamente.

Numa palavra: aqui temos também uma crença na possibilidade da conciliação entre interesses inconciliáveis. Todavia, na luta de classes, a política de conciliação não significa empate. Em última instância, é sempre a classe trabalhadora que perde, sendo mantidas as suas condições (econômicas e ideológicas) de exploração, mesmo que em circunstâncias que possam se apresentar mais favoráveis - circunstâncias essas sempre passageiras no capitalismo; para não falar no capitalismo periférico, onde elas são mesmo limitadíssimas e extremamente efêmeras. Nesse sentido, não há empate na conciliação de classes. Isso por uma razão simples: uma pretensa situação de equilíbrio não é tolerável para a própria classe que personifica a ânsia de acumulação (a classe capitalista) - ou ela se favorece de algum modo, ou não aceita os termos em jogo na vida econômica e política. Isso está sendo provado historicamente no Brasil atual, com a crise econômica e os intensos reveses políticos que ela está engendrando. Mas a própria crise está ensinando aos/as trabalhadores/ as como funcionam os mecanismos da dominação burguesa - o que opera, por exemplo, pela a ampla projeção pública da corrupção intrínseca à relação do grande capital com o seu Estado. Essa lição histórica os conduz, portanto, a perder a ilusão sobre o significado da conciliação de classes. Por isso, o tema do Dia do/a Assistente Social de 2017 é muitíssimo oportuno, como síntese didática da ilusão que precisa ser suplantada. Mas esse tema também vocaliza uma perspectiva de mais longo prazo para o enfrentamento da crise. ${ }^{12}$ Pois o reverso positivo da negativa na luta de classes não há empate é: a única saída efetiva para os/as trabalhadores/as é garantir a independência de classe.

A afirmação dessa posição, no campo de possibilidades dados ao Serviço Social, implica em iniciativas nos planos téorico-político e interventivo. No primeiro, o rompimento com a conciliação se expressa no resgate e aprofundamento do estudo (e a difusão) da tradição socialista revolucionária (vinculada ao pensamento de Marx), nas suas elaborações sobre a estrutura econômica capitalista, mas também acerca da dinâmica da luta de classes e das ideologias a ela correspondentes. Aliando-se a isso o investimento na crítica teórica sistemática às vertentes antimarxistas (e anticomunistas) e irracionalistas do pensamento social contemporâneo. Iniciativas necessárias para subsidiar o esforço central que precisa ser feito de análise concreta dos fenômenos sociais emergentes, aportando-se na visão da luta de classes e na perspectiva de totalidade - sem concessões ao produtivismo acadêmico que impacta no esvaziamento da relevância social das pesquisas e da sua consistência teórico-política. No plano interventivo, é necessária uma firme recusa de abordagens/metodologias individualizadoras, moralizadoras e criminalizadoras que tendem a ganhar ênfase nas reconfigurações das políticas sociais face à agenda restauradora. Uma recusa necessariamente articulada a uma agenda positiva, centrada no incentivo e apoio a iniciativas - que brotam da crise social - de mobilização e auto-organização das frações de classe alvos das políticas sociais. A partir de onde o Serviço Social pode investir produtivamente na abertura de espaços de politização da reflexão sobre os impactos da crise e suas alternativas.

\section{Referências}

ALVES, G. Trabalho e neodesenvolvimentismo - choque de capitalismo e nova degradação do trabalho no Brasil. Bauru: Canal 6, 2014. ANANIAS, P. Sobre o dever de mudar a realidade: o papel do Estado na promoção de políticas sociais em um modelo de desenvolvimento integral. In: COELHO, M. F. P.; TAPAJÓS, L. M. de S.; RODRIGUES, M. (Org.). Políticas sociais para o desenvolvimento: superar a pobreza e promover a inclusão. Brasília, DF: MDS/UNESCO, 2010. p. 315-332.

ANDERSON, P. A crise no Brasil, por Perry Anderson (parte 1). Esquerda. Net, 23 abr. 2016. Disponível em: <http://www.esquerda.net/ printpdf/42445>. Acesso em: 26 abr. 2016.

ASSOCIAÇÃO NACIONAL DOS AUDITORES FISCAIS DA RECEITA FEDERAL DO BRASIL. Análise da Seguridade Social 2015. Brasília, DF: ANFIP, 2016.

; DEPARTAMENTO INTERSINDICAL DE ESTATÍSTICA E ESTUDOS SOCIOECONÔMICOS. Previdência: reformar 
para excluir? Contribuição técnica ao debate sobre a reforma da previdência social brasileira. Brasília, DF: ANFIP; DIEESE, 2017. BAVA, S. C. As grandes empresas e a corrupção. Le monde diplomatique (Brasil), ano 10, n. 117, p. 3, abr. 2017.

BRAGA, R. Terra em transe: o fim do lulismo e o retorno da luta de classes. In: SINGER, A.; LOUREIRO, I. (Org.). As contradições do lulismo: a que ponto chegamos? São Paulo: Boitempo, 2016. p. 55-92.

BRASIL. Código de ética do/a assistente social. Lei 8.662/93 de regulamentação da profissão. 10. ed. Brasília, DF: CFESS, 2012.

. Decreto n. 8.456, de 22 de maio de 2015. Dispõe sobre a programação orçamentária e financeira, estabelece o cronograma mensal de desembolso do Poder Executivo para o exercício de 2015, e dá outras providências. Diário Oficial da União, Brasília, DF, 22 maio 2015f. Disponível em: <http://www.planalto.gov.br/ccivil_03/_ato2015-2018>. Acesso em: 20 abr. 2017.

. Decreto n. 8.496, de 30 de julho de 2015. Altera o Decreto n. 8.456, de 22 de maio de 2015, que dispõe sobre a programação orçamentária e financeira, estabelece o cronograma mensal de desembolso do Poder Executivo para o exercício de 2015, e dá outras providências. Diário Oficial da União, Brasília, DF, 30 jul. 2015e. Disponível em: <http://www.planalto.gov.br/ccivil_03/_ato20152018/2015/decreto/d8496.htm>. Acesso em: 20 abr. 2017.

. Emenda Constitucional n. 93, de 8 de setembro de 2016. Altera o Ato das Disposições Constitucionais Transitórias para prorrogar a desvinculação de receitas da União e estabelecer a desvinculação de receitas dos Estados, Distrito Federal e Municípios. Diário Oficial da União, Brasília, DF, 9 set. 2016d. Disponível em: <http://www.planalto.gov.br/ccivil_03/constituicao/emendas/emc/ emc93.htm>. Acesso em: 20 abr. 2017.

. Lei n. 13.134, de 16 de junho de 2015. Altera as Leis n. 7.998, de 11 de janeiro de 1990, que regula o Programa do SeguroDesemprego e o Abono Salarial e institui o Fundo de Amparo ao Trabalhador (FAT), n. 10.779, de 25 de novembro de 2003, que dispõe sobre o seguro-desemprego para o pescador artesanal, e n. 8.213, de 24 de julho de 1991, que dispõe sobre os planos de benefícios da Previdência Social; revoga dispositivos da Lei n. 7.998, de 11 de janeiro de 1990, e as Leis n. 7.859, de 25 de outubro de 1989, e n. 8.900, de 30 de junho de 1994; e dá outras providências. Diário Oficial da União, Brasília, DF, 17. jun. 2015c. Disponível em: <http:// www.planalto.gov.br/ccivil_03/_Ato2015-2018/2015/Lei/L13134.htm>. Acesso em: 20 abr. 2017.

. Lei n. 13.135, de 17 de junho de 2015. Altera as Leis n. 8.213, de 24 de julho de 1991, n. 10.876, de 2 de junho de 2004, n. 8.112, de 11 de dezembro de 1990, e n. 10.666, de 8 de maio de 2003, e dá outras providências. Diário Oficial da União, Brasília, DF, 18 jun. 2015d. Disponível em: <http://www.planalto.gov.br/ccivil_03/_ato2015-2018/2015/lei/113135.htm>. Acesso em: 20 abr. 2017.

. Lei n. 13.189, de 19 de novembro de 2015. Institui o Programa Seguro-Emprego (PSE). Diário Oficial da União, Brasília, DF, 20 nov. 2015h. Disponível em: <http://www.planalto.gov.br/ccivil_03/_ato2015-2018/>. Acesso em: 20 abr. 2017.

. Lei n. 13.254, de 13 de janeiro de 2016. Dispõe sobre o Regime Especial de Regularização Cambial e Tributária (RERCT) de recursos, bens ou direitos de origem lícita, não declarados ou declarados incorretamente, remetidos, mantidos no exterior ou repatriados por residentes ou domiciliados no País. Diário Oficial da União, Brasília, DF, 14 jan. 2016f. Disponível em: <http://www.planalto.gov.br/ ccivil_03/_Ato2015-2018/2016/Lei/113254.htm>.Acesso em: 20 abr. 2017.

. Lei n. 13.291, de 25 de maio de 2016. Altera os dispositivos que menciona da Lei n. 13.242, de 30 de dezembro de 2015, que dispõe sobre as diretrizes para a elaboração e execução da Lei Orçamentária de 2016. Diário Oficial da União, Brasília, DF, 27 maio 2016e. Disponível em: <https://presrepublica.jusbrasil.com.br/legislacao/342461062/lei-13291-16>. Acesso em: 20 abr. 2017.

. Lei n. 13.299, de 21 de junho de 2016. Altera a Lei n. 9.074, de 7 de julho de 1995, a Lei n. 9.427, de 26 de dezembro de 1996, a Lei n. 10.438, de 26 de abril de 2002, a Lei n. 12.111, de 9 de dezembro de 2009, a Lei n. 12.783, de 11 de janeiro de 2013, que dispõe sobre as concessões de geração, transmissão e distribuição de energia elétrica, e a Lei n. 13.182, de 3 de novembro de 2015; e dá outras providências. Diário Oficial da União, Brasília, DF, 22 jun. 2016i. Disponível em: <http://www.planalto.gov.br/ccivil_03/_ato20152018/2016/lei/L13299.htm>. Acesso em: 20 abr. 2017.

. Lei n. 13.303, de 30 de junho de 2016. Dispõe sobre o estatuto jurídico da empresa pública, da sociedade de economia mista e de suas subsidiárias, no âmbito da União, dos Estados, do Distrito Federal e dos Municípios. Diário Oficial da União, Brasília, DF, 1 jul. 2016g. Disponível em: <http://www.planalto.gov.br/ccivil_03/_ato2015-2018/2016/lei/113303.htm>. Acesso em: 20 abr. 2017.

. Lei n. 13.334, de 13 de setembro de 2016. Cria o Programa de Parcerias de Investimentos - PPI; altera a Lei n. 10.683, de 28 de maio de 2003, e dá outras providências. Diário Oficial da União, Brasília, DF, 13 set. 2016h. Disponível em: <http://www.planalto.gov.br/ ccivil_03/_ato2015-2018/2016/lei/L13334.htm>. Acesso em: 20 abr. 2017.

. Lei n. 13.360, de 17 de novembro de 2016. Altera a Lei n ${ }^{\circ} 5.655$, de 20 de maio de 1971, a Lei ${ }^{\circ} 10.438$, de 26 de abril de 2002, ${\text { a Lei }{ }^{\circ}}^{\circ}$ 9.648, de 27 de maio de 1998, a Lei no 12.111, de 9 de dezembro de 2009, a Lei no 12.783, de 11 de janeiro de 2013, a Lei $n^{\circ} 9.074$, de 7 de julho de 1995, a Lei $n^{\circ} 7.990$, de 28 de dezembro de 1989, a Lei $n^{\circ} 9.491$, de 9 de setembro de 1997, a Lei $n^{\circ} 9.427$, de 26 de dezembro de 1996, a Lei ${ }^{\circ} 10.848$, de 15 de março de 2004, a Lei no 11.488 , de 15 de junho de 2007, a Lei no 12.767 , de 27 de dezembro de 2012, a Lei $\mathrm{n}^{\circ}$ 13.334, de 13 de setembro de 2016, a Lei $\mathrm{n}^{\circ}$ 13.169, de 6 de outubro de 2015, a Lei $\mathrm{n}^{\circ} 11.909$, de 4 de março de 2009 , e a Lei n ${ }^{\circ} 13.203$, de 8 de dezembro de 2015; e dá outras providências. Diário Oficial da União, Brasília, DF, 18 nov. 2016j. Disponível em: <http://www.planalto.gov.br/ccivil_03/_ato2015-2018/2016/lei/L13360.htm>. Acesso em: 20 abr. 2017.

. Lei n. 13.365, de 29 de novembro de 2016. Altera a Lei n. 12.351, de 22 de dezembro de 2010, para facultar à Petrobras o direito de preferência para atuar como operador e possuir participação mínima de 30\% (trinta por cento) nos consórcios formados para exploração de blocos licitados no regime de partilha de produção. Diário Oficial da União, Brasília, DF, 30 nov. 2016k. Disponível em: <http://www.planalto.gov.br/ccivil_03/_ato2015-2018/2016/lei/L13365.htm>. Acesso em: 20 abr. 2017.

. Lei n. 13.415, de 16 de fevereiro de 2017. Altera as Leis n. 9.394, de 20 de dezembro de 1996, que estabelece as diretrizes e bases 
da educação nacional, e 11.494, de 20 de junho 2007, que regulamenta o Fundo de Manutenção e Desenvolvimento da Educação Básica e de Valorização dos Profissionais da Educação, a Consolidação das Leis do Trabalho - CLT, aprovada pelo Decreto-Lei n. 5.452, de 1 de maio de 1943, e o Decreto-Lei n. 236, de 28 de fevereiro de 1967; revoga a Lei n. 11.161, de 5 de agosto de 2005; e institui a Política de Fomento à Implementação de Escolas de Ensino Médio em Tempo Integral. Diário Oficial da União, Brasília, DF, 17 fev. $2017 \mathrm{~b}$. Disponível em: <http://www.planalto.gov.br/ccivil_03/_ato2015-2018/2017/lei/L13415.htm>. Acesso em: 20 abr. 2017.

Medida Provisória n. 664, 30 dez. 2014. Altera as Leis n ${ }^{\circ}$ s 8.213, de 24 de julho de 1991, 10.876, de 2 de junho de 2004, 8.112, de 11 de dezembro de 1990, e 10.666, de 8 de maio de 2003; e dá outras providências. Transformada na Lei Ordinária n. 13.135/2015. Câmara dos Deputados, Brasília, DF, [2015a]. Disponível em: <http://www.camara.gov.br/proposicoesWeb/ fichadetramitacao?idProposicao=865929>. Acesso em: 20 abr. 2017.

. Medida Provisória n. 665, 30 dez. 2014. Altera as Leis nº 7.998, de 11 de janeiro de 1990, que regula o Programa do SeguroDesemprego, o Abono Salarial e institui o Fundo de Amparo ao Trabalhador - FAT, 10.779, de 25 de novembro de 2003, que dispõe sobre o seguro-desemprego para o pescador artesanal, e 8.213, de 24 de julho de 1991; revoga as Leis $\mathrm{n}^{\circ} \mathrm{s} 7.859$, de 25 de outubro de 1989, e 8.900, de 30 de junho de 1994; e dá outras providências. Transformada na Lei Ordinária n. 13.134/2015. Câmara dos Deputados, Brasília, DF, [2015b]. Disponível em: <http://www.camara.gov.br/proposicoesWeb/fichadetramitacao?idProposicao=865930>. Acesso em: 20 abr. 2017.

. Medida Provisória n. 680, de 6 de julho de 2015. Institui o Programa de Proteção ao Emprego e dá outras providências. Câmara dos Deputados, Brasília, DF, [2015g]. Disponível em: <http://www.camara.gov.br/proposicoesWeb/ fichadetramitacao?idProposicao=1554014>. Acesso em: 20 abr. 2017.

. Medida Provisória 746, 23 set. 2016. Institui a Política de Fomento à Implementação de Escolas de Ensino Médio em Tempo Integral, altera a Lei n ${ }^{\circ}$ 9.394, de 20 de dezembro de 1996, que estabelece as diretrizes e bases da educação nacional, e a Lei $n^{\circ} 11.494$ de 20 de junho 2007, que regulamenta o Fundo de Manutenção e Desenvolvimento da Educação Básica e de Valorização dos Profissionais da Educação, e dá outras providências. Transformada na Lei Ordinária n. 13.415/2017. Câmara dos Deputados, Brasília, DF, [2017a]. Disponível em: <http://www.camara.gov.br/proposicoesWeb/fichadetramitacao?idProposicao=2112490>. Acesso em: 20 abr. 2017.

Projeto de Lei n. 4.320, de 24 de março de 1998. Introduz alterações na Lei nº 9.393, de 1996. Câmara dos Deputados, Brasília, DF, [2000]. Disponível em: <http://www.camara.gov.br/proposicoesWeb/fichadetramitacao?idProposicao=41317>. Acesso em: 20 abr. 2017.

Projeto de Lei n. 6.787, de 23 de dezembro de 2016. Altera o Decreto-Lei n ${ }^{\circ} 5.452$, de $1^{\circ}$ de maio de 1943 - Consolidação das Leis do Trabalho, e a Lei $n^{\circ} 6.019$, de 3 de janeiro de 1974, para dispor sobre eleições de representantes dos trabalhadores no local de trabalho e sobre trabalho temporário, e dá outras providências. Câmara dos Deputados, Brasília, DF, [2017e]. Disponível em: <http:/ /www.camara.gov.br/proposicoesWeb/fichadetramitacao?idProposicao>. Acesso em: 20 abr. 2017.

. Projeto de Lei Complementar n. 268, de 19 abr. 2016. Altera a Lei Complementar no 108, de 29 de maio de 2001, para aprimorar os dispositivos de governança das entidades fechadas de previdência complementar vinculadas à União, aos Estados, ao Distrito Federal e aos Municípios e a suas autarquias, fundações, sociedades de economia mista e outras entidades públicas. Câmara dos Deputados, Brasília, DF, [2017c]. Disponível em: $<$ http://www.camara.gov.br/proposicoesWeb/fichadetramitacao?idProposicao=2082269>. Acesso em: 20 abr. 2017.

Projeto de Lei da Câmara n. 30, de 2015. Dispõe sobre os contratos de terceirização e as relações de trabalho deles decorrentes. Senado Federal, Brasília, DF, [2017d]. Disponível em: <https://www25.senado.leg.br/web/atividade/materias/-/materia/120928>. Acesso em: 20 abr. 2017.

. Projeto de Lei do Senado n. 193, 2016. Inclui entre as diretrizes e bases da educação nacional, de que trata a Lei n. 9.394, de 20 de dezembro de 1996, o "Programa Escola sem Partido". Senado Federal, Brasília, DF, [2016b]. Disponível em: < https:// www25.senado.leg.br/web/atividade/materias/-/materia/125666>. Acesso em: 20 abr. 2017.

Proposta de Emenda à Constituição n. 287, de 5 de dezembro de 2016. Altera os arts. 37, 40, 109, 149, 167, 195, 201 e 203 da Constituição, para dispor sobre a seguridade social, estabelece regras de transição e dá outras providências. Câmara dos Deputados, Brasília, DF, [2016c]. Disponível em: <proposicoesWeb/fichadetramitacao?idProposicao=2119881>. Acesso em: 20 abr. 2017.

. Proposta de Emenda Constitucional n. 241, 2016. Transformada na Emenda Constitucional n. 95, em 15 dez. 2016. Teto dos Gastos Públicos. Altera o Ato das Disposições Constitucionais Transitórias, para instituir o Novo Regime Fiscal, e dá outras providências. Diário Oficial da União, Brasília, DF, 16 dez. 2016a, seção 1, p. 2.

CASTRO, M. M. História do serviço social na América Latina. 5. ed. São Paulo: Cortez, 2000.

CONFEDERAÇÃO NACIONAL DAS INDÚSTRIAS. Indicadores Industriais, ano 17, n. 8, ago. 2015.

CONSELHO FEDERAL DE SERVIÇO SOCIAL. Serviço Social é noticia-Informativo do Conjunto CFESS-CRESS, ano 3, n. 3, maio 2017.

DEPARTAMENTO INTERSINDICAL DE ESTATÍSTICA E ESTUDOS SOCIOECONÔMICOS. PEC $n^{\circ}$ 241/2016: o novo regime fiscal e seus possíveis impactos. Nota Técnica n 161, set. 2016. Disponível em: <https://www.dieese.org.br/notatecnica/2016/ notaTec161novoRegimeFiscal.pdf $>$. Acesso em: 22 out. 2016.

FUNDO MONETÁRIO INTERNACIONAL. World Economic Outlook: Adjusting to Lower Commodity Prices. Washington (Outubro), 2015. Disponível em: <http://www.imf.org/external/pubs/ft/weo/2015/02/> Acesso em: 10 nov. 2015. 
GRAMSCI, A. Cadernos do cárcere: introdução ao estudo da filosofia e a filosofia de Benedetto Croce. 5. ed. Rio de Janeiro: Civilização Brasileira, 2011a. v. 1.

. Cadernos do cárcere: os intelectuais. O princípio educativo. Jornalismo. 6. ed. Rio de Janeiro: Civilização Brasileira, 2011b. v. 2. IAMAMOTO, M.; CARVALHO, R. de. Relações sociais e Serviço Social no Brasil: esboço de uma interpretação histórico-metodológica. 18. ed. São Paulo: Cortez, 2005.

KATZ, C. Neoliberalismo, neodesarrollismo, socialismo. Buenos Aires: Batalla de Ideas, 2015.

LUCE, M. Brasil: nova classe média ou novas formas de superexploração da classe trabalhadora? Trabalho, Educação e Saúde, v. 11, n. 1, p.169-190, abr. 2013.

MARX, K. O capital: crítica da economia política. Livro 1: o processo de produção do capital. São Paulo: Boitempo, 2013.

MOTA, A. E. 80 anos do Serviço Social brasileiro: conquistas históricas e desafios na atual conjuntura. Serviço Social \& Sociedade, São Paulo, n. 128, p. 39-53, abr. 2017.

NETTO, J. P. Ditadura e Serviço Social. 7. ed. São Paulo: Cortez, 2004.

. Transformações societárias e Serviço Social: notas para uma análise prospectiva da profissão no Brasil. Serviço Social \& Sociedade, São Paulo, n. 50, p. 87-132, abr. 1996.

NORONHA, E. G. Ciclo de greves, transição política e estabilização: Brasil, 1978- 2007. Lua Nova, v. 76, p. 119-168, 2009.

PARTIDO DO MOVIMENTO DEMOCRÁTICO BRASILEIRO. Uma ponte para o futuro. Brasília, DF, 29 out. 2015. Documento. Disponível em: <http://pmdb.org.br/wp-content/uploads/2015/10/RELEASE-TEMER_A4-28.10.15-Online.pdf >.Acesso em: 2 out. 2016. POCHMANN, M. Nova classe média? O trabalho na base da pirâmide social brasileira. São Paulo: Boitempo, 2012.

QUEIROZ, A. A. de. O desmonte do Estado de proteção social. Le monde diplomatique (Brasil), ano 10, n. 117, p. 4-5, abr. 2017.

SERVIÇO SOCIAL \& SOCIEDADE, São Paulo, n. 112, out./dez. 2012. Disponível em: <http://www.scielo.br/ scielo.php?script=sci_issuetoc $>$. Acesso em: 2 out. 2016.

SINGER, A.; LOUREIRO, I. As contradições do Lulismo: a que ponto chegamos? São Paulo: Boitempo, 2016.

WOOD, E. M. Democracia contra capitalismo. São Paulo: Boitempo, 2003.

\section{Notas}

1 Desde já, advertimos para o fato de não abordarmos, nesse texto, a ascensão de ideologias e movimentos políticos próprios do conservadorismo contemporâneo, cujas linhas de evolução parecem guardar estreita relação com o evolver da crise econômica. No artigo, privilegiamos as questões relacionadas à política econômica e à movimentação social das classes trabalhadoras e subalternas (no limite, também das classes médias).

2 Um caso emblemático consiste numa passagem de O Capital (MARX, 2013, p. 223), no qual seu autor assinala a alteração do provérbio medieval nulle terre sansmaître (nenhuma terra sem senhor) para l'argent n'a pas de maître (o dinheiro não tem dono), indicando, no plano das relações cotidianas, uma reviravolta radical cuja consumação final evidencia-se no sistema do capital plenamente desenvolvido.

3 Trabalhamos com a hipótese da existência de intervalos de expansão e/ou estagnação dentro da tendência média, de mais longa duração, de crise estrutural, conformada após 1970 na totalidade dos países capitalistas em nível mundial.

4 Para essa análise, além do conjunto de artigos publicados na revista Serviço Social \& Sociedade n 112 (2012), indicamos os trabalhos de Alves (2014), Anderson (2016), Katz (2015) e Singer e Loureiro (2016).

5 O relatório do Fundo Monetário Internacional (FMI), World Economic Outlook: Adjusting to Lower Commodity Prices (out. 2015), registra essa queda no faturamento industrial e no comercio mundial que se inicia em 2010. Um balanço geral da crise brasileira, sob essa perspectiva das relações internacionais, é apresentado por Anderson (2016).

6 Semmencionar aqui aquelas iniciativas que avançavam, em 2015, na Câmara eno Senado, para atacar outros direitos dos/as trabalhadores/as (PDC 1.358/13; PL 8.294/14; PL 4.193/12; PL 7.341/14; PL 450/15; PEC 18/11; PDC 1.408/13), a aprovação (na Câmara) do Projeto de Lei que expandia a terceirização, a proposta de pacote de medidas (ago. 2015) para a contenção de gastos federais (suspensão de concursos, adiamento de reajuste, etc.) e as pautas conservadoras de redução da maioridade penal e do Estatuto da Família.

7 Esse conteúdo local ou nacional representa o volume mínimo de equipamentos e serviços produzidos no país que são exigidos em licitações de exploração de algumas indústrias, como petróleo e gás, como critério para a definição de vencedores, para garantir a participação da indústria nacional.

8 Interessante notar que, com a crise do governo de Michel Temer, que avança em finais de maio de 2017, após a divulgação de denúncias envolvendo o próprio Presidente, essa base tende a se esvair do seu apoio, embora mantendo a premissa de defesa das contrarreformas.

9 Uma competente síntese crítica da doutrina e ideologia do Desenvolvimento de Comunidade encontra-se em Castro (2000).

10 Essa análise encontra-se pormenorizada nos trabalhos de Castro (2000), Iamamoto e Carvalho (2005) e Netto (2004).

11 Veja-se, por exemplo, as linhas de desenvolvimento que Netto (1996) projetava em torno das vertentes teórico-profissionais do Serviço Social em meados de 1990, dentre as quais o autor vislumbrava uma de cariz tecnocrático e outra nomeada de reatualização do conservadorismo.

12 Nesse momento de ameaça ao próprio governo de Michel Temer, isso se torna particularmente importante, pois as alternativas imediatas que estão sendo esboçadas caminham: seja para uma saída exclusiva pelo alto, através de eleições indiretas (hipótese que demandará um aprofundamento da luta em torno dos interesses dos/as trabalhadores/as); seja para uma reentrada em cena de Lula através de eleições diretas, tentando estender a promessa da conciliação já bastante desgastada (via que colocará em prova a erosão da saída conciliatória em face dos/as trabalhadores/as, 
demandando a defesa de estratégias com independência de classe). Caso essa última via prevaleça, ela significará - pelo que as relações de forças internas e internacionais nos indicam - o capítulo derradeiro do reformismo tupiniquim de cunho social-liberal.

\section{Adilson Aquino Silveira Júnior}

j_r1987@hotmail.com

Doutorado em Serviço Social pela Universidade Federal de Pernambuco (UFPE)

Professor do Departamento de Serviço Social da Universidade Federal de Pernambuco (UFPE)

\section{UFPE}

Av. Prof. Moraes Rego, 1235 - Cidade Universitária

Recife - Pernambuco - Brasil

CEP: $50.670-901$ 